\title{
BRPKM
}

Buletin Riset Psikologi dan Kesehatan Mental

http://e-journal.unair.ac.id/index.php/BRPKM

e-ISSN: 2776-1851

ARTIKEL PENELITIAN

\section{Hubungan antara Gangguan Emosional dengan Emotional Eating dan External Eating pada Masa Pandemi COVID-19}

\author{
ELVIA AGUSTYA TRISNAWATI \& DIMAS ARYO WICAKSONO* \\ Fakultas Psikologi Universitas Airlangga
}

\begin{abstract}
ABSTRAK
Penelitian ini bertujuan untuk mengetahui dan menganalisis apakah terdapat hubungan antara gangguan emosional dengan emotional eating dan external eating selama masa pandemi COVID-19. Penelitian ini merupakan penelitian kuantitatif dengan metode pengumpulan data survei. Penelitian ini melibatkan 217 responden. Instrumen pengumpulan data berupa kuesioner yang mencakup skala Depression Anxiety and Stress Scale yang disusun oleh Lovibond \& Lovibond dan skala Dutch Eating Behavior Questionnaire yang disusun oleh Van Strien. Analisis data dilakukan dengan menggunakan uji Kruskal-Wallis dengan bantuan perangkat lunak Jamovi 1.1.4.0 for Windows. Hasil dari penelitian ini menunjukkan bahwa terdapat hubungan yang signifikan dan bersifat positif antara depresi dengan emotional eating. Selain itu juga terdapat hubungan yang signifikan dan bersifat positif antara kecemasan dengan external eating pada masa pandemi COVID-19. Kemudian, terdapat hubungan yang tidak signifikan dan bersifat positif pada empat dimensi gangguan emosional dengan emotional eating dan external eating pada masa pandemi COVID-19.
\end{abstract}

Kata kunci: emotional eating, external eating, gangguan emosional

\begin{abstract}
This study aims to determine and analyze whether there is a relationship between emotional disorders with emotional eating and external eating during the COVID-19 pandemic. This study uses a quantitative research design with survey data collection methods. This study involved 217 respondents The data collection instrument is a questionnaire including the Dutch Eating Behavior Questionnaire compiled by Lovibond \& Lovibond and the Dutch Eating Behavior Questionnaire scale compiled by Van Strien. Data analysis was performed using Kruskal-Wallis test with the help of Jamovi 1.1.4.0 software for Windows. The results of this study showed that there is a significant and positive relationship between depression and emotional eating during the COVID-19 pandemic. In addition, there is also a significant and positive relationship between anxiety and external eating during the COVID-19 pandemic. Then, there is an insignificant and positive relationship on the four dimensions of emotional disorders with emotional eating and external eating during the COVID-19 pandemic.
\end{abstract}

Keywords: emotional disorder, emotional eating, external eating

Buletin Penelitian Psikologi dan Kesehatan Mental (BRPKM), 2021, Vol. 1(2), 1282-1289

*Alamat korespondensi: Fakultas Psikologi Universitas Airlangga, Kampus B Universitas Airlangga Jalan Airlangga 4-6 Surabaya 60286. Surel: aryo.wicaksono@psikologi.unair.ac.id 
sehingga penggunaan, distribusi, reproduksi dalam media apapun atas artikel ini tidak dibatasi, selama sumber aslinya disitir dengan baik.

\section{P E N D A H U L U A N}

Adanya virus COVID-19 ini masyarakat di Indonesia merasakan dampak yang cukup besar dari berbagai bidang. Salah satunya adalah perilaku konsumsi makanan. Penelitian yang dilakukan oleh (Efrizal, 2020) menjelaskan bahwa tingkat konsumsi masyarakat selama pandemi COVID-19 mengalami perubahan yang dapat dilihat dari besaran pengeluaran yang lebih mengutamakan untuk makanan, kesehatan, dan pendidikan. Industri makanan dan minuman merupakan salah satu sektor yang terkena dampak cukup besar dari adanya virus COVID-19 ini. Adanya batasan dan larangan untuk melakukan interaksi sosial selama pandemi COVID-19 juga memengaruhi penurunan penjualan makanan dan minuman yang sangat ekstrem (Prakoso, 2020). Waktu akhir pekan yang biasanya digunakan untuk refreshing atau makan bersama keluarga di luar rumah pun juga dilarang karena dalam aturan PSBB konsumen dilarang untuk makan di tempat dan dihimbau untuk membeli makanan kemudian dibawa pulang atau bisa juga menggunakan sistem drive-thru. Bukan hanya karena adanya peraturan PSBB, namun memang terdapat kekhawatiran untuk keluar rumah yang dapat memicu terinfeksi virus COVID19.

Bagi sebagian masyarakat, toko bahan makanan merupakan salah satu dari beberapa tempat umum yang dikunjungi selama pandemi COVID-19. Sehingga belanja makanan dapat meningkatkan risiko tertularnya virus COVID-19 untuk berbagi ruang dalam ruangan (Allen \& Marr, 2020). Membeli bahan makanan dalam jumlah besar pun juga dijelaskan dalam penelitian (Jeżewska-Zychowicz dkk., 2020), dimana terdapat peningkatan sebesar 9\% kemungkinan membeli bahan makanan dalam jumlah yang lebih besar daripada biasanya dengan stres yang dirasakan lebih tinggi. Penelitian ini juga menjelaskan bahwa terdapat $130 \%$ kekhawatiran yang meningkat akan terbatasnya akses makanan saat virus COVID-19 semakin tersebar luas.

Van Strien dkk. (dalam Putri, 2015) menjelaskan bahwa terdapat tiga aspek dalam perilaku makan, yaitu emotional eating, external eating, dan restrained eating. Emotional eating merupakan sebuah perilaku makan untuk memperlihatkan respon yang menandakan kemarahan, seperti marah, takut, cemas, dan yang lainnya. Mengonsumsi makanan dilakukan dengan tujuan untuk menghilangkan stres yang dialaminya sementara dan tidak memedulikan rasa lapar yang muncul dari dalam tubuh. Alasan seseorang mengonsumsi makanan adalah karena respon yang muncul karena emosi yang dialaminya, bukan karena adanya rasa lapar yang muncul dari dalam tubuh. Seseorang akan mengonsumsi makanan secara berlebihan ketika sedang menghadapi emosi yang tinggi. Menurut Zellner dkk. (2006, dalam Sonya, 2019) seseorang akan mengonsumsi makanan dengan kalori yang tinggi dan berhubungan dengan lemak di badan. Sedangkan external eating merupakan sebuah perilaku makan untuk memerlihatkan respon terhadap rangsangan yang berhubungan dengan makanan terlepas dari kondisi internal rasa lapar atau kenyang. Menurut Schachter, Goldman \& Gordon (1968, dalam Sonya, 2019) seseorang makan karena adanya dorongan yang berasal dari lingkungan sekitar terutama stimulus eksternal makanan, seperti ketersedian makanan, aroma makanan, dan cita rasa makanan.

Selanjutnya dengan berbagai kegiatan yang dibatasi seperti sekolah dan kerja yang harus dilakukan dari rumah juga dapat memperburuk obesitas dan meningkatkan jarak dalam risiko obesitas (Ben Hassen dkk., 2020). Kegiatan sekolah dan kerja yang dilakukan di rumah, aktivitas fisik individu akan menurun dan mereka melewatkan jadwal-jadwal yang sebelumnya telah biasa dilakukan, seperti jadwal makan 
siang dan jadwal kegiatan yang lainnya. Adanya kebijakan isolasi mandiri di rumah selama pandemi COVID-19 mengakibatkan tingginya prevalensi tekanan psikologis (Brooks dkk., 2020).

Berhubungan dengan berbagai perilaku yang muncul akibat dari virus COVID-19 ini, fungsi mental dan sosial secara signifikan memburuk karena stres dan tekanan emosional yang timbul dari banyaknya hal yang tidak diketahui terkait dengan ketersediaan makanan, isolasi, proses sekolah dan kerja yang tidak seperti biasanya, dan banyaknya informasi yang masuk (Galanakis, 2020). Stres, kecemasan, tekanan emosi, dan depresi adalah emosi yang terkait dengan perilaku makan yang tidak diinginkan (Devonport dkk., 2019). Stres dan tekanan emosi yang terjadi ini diperkuat oleh media massa yang menginformasikan secara luas mengenai pesatnya peningkatan dalam morbiditas dan mortalitas serta ketersediaan bahan makanan yang terbatas. Beberapa penelitian telah menemukan hubungan positif antara keterbatasan makanan dan masalah kesehatan mental (Hernandez dkk., 2019). Kelelahan fisik dan emosional dari paparan stres secara langsung dapat mengganggu pola makan dan nutrisi. Meskipun stres akut biasanya menekan nafsu makan, stres yang terus-menerus memberikan tanda kelenjar adrenal untuk melepaskan kortisol sehingga dapat meningkatkan nafsu makan, motivasi untuk makan, dan konsumsi makanan padat energi yang enak yang tinggi kalori, gula, dan lemak (Shen dkk., 2020).

Menurut Grunert (1993) perilaku konsumsi makanan merupakan fenomena interaksi antara faktor sosial budaya, fisiologis, ekonomi, dan psikologi. Adanya interaksi tersebut mengubah arti dari perilaku mengonsumsi makanan sebagai kebutuhan untuk memenuhi nutrisi menjadi sebuah pola kebiasaan makan yang kompleks (Fassah \& Retnowati, 2014) Gangguan emosional adalah kondisi dimana tanggapan atas perilaku atau emosional seseorang berbeda pada umumnya. Gangguan emosi menurut Asif \& Rahmadi (2017) merupakan kesulitan yang dirasakan saat menyesuaikan diri dan tidak sesuai dengan norma-norma yang berlaku di masyarakat pada umumnya sehingga dapat merugikan diri sendiri ataupun orang lain. Dengan adanya perilaku emotional eating dan external eating di masa pandemi ini dapat memicu terjadinya gangguan emosional berupa stres, kecemasan, dan depresi yang disebabkan oleh terbatasnya akses untuk mendapatkan bahan makanan dan pertimbangan untuk keluar rumah.

Berdasarkan penjelasan tersebut membuat peneliti ingin mengeksplorasi apakah terdapat hubungan antara gangguan emosional dengan emotional eating dan external eating pada masa pandemi COVID-19. Pertanyaan dalam penelitian ini berfokus pada hubungan antara stres dengan emotional eating, stres dengan external eating, kecemasan dengan emotional eating, kecemasan dengan external eating, depresi dengan emotional eating, dan depresi dengan external eating.

\section{E T O D E}

\section{Desain Penelitian}

Penelitian ini menggunakan pendekatan kuantitatif-survei dengan desain penelitian survei crosssectional. Data dikumpulkan dengan menyebarkan kuesioner secara online melalui Google Form. Kuesioner ini berisikan dua skala, yaitu Depression Anxiety and Stress Scale (DASS) untuk mengukur gangguan emosional, yaitu depresi, kecemasan, dan stres. Dutch Eating Behavior Questionnaire (DEBQ) untuk mengukur emotional eating dan external eating. Uji validitas menggunakan teknik validitas isi (content validity) dengan metode Content Validity Index (CVI) atau indeks validitas isi. Sedangkan untuk reliabilitas menggunakan koefisien Cronbach Alpha. Analisa data yang digunakan adalah teknik kruskal wallis dengan bantuan program Jamovi 1.6.21 for Windows. 


\section{Partisipan}

Partisipan dalam penelitian ini adalah generasi milenial yang berusia 20 hingga 40 tahun. Teknik yang digunakan adalah non-probability sampling. Untuk memperkirakan jumlah sampel yang akan diteliti, peneliti menggunakan aplikasi $G^{*}$ Power 3.1.9.4. Dengan perhitungan $G^{*}$ Power tersebut, maka dapat diperkirakan jumlah sampel yang dibutuhkan pada penelitian ini minimal sebanyak 89 orang. Penelitian melibatkan 217 partisipan ( $M_{\text {usia }}=22 ; S D_{\text {usia }}=42,30 ; 69,6$ persen perempuan $)$.

\section{Pengukuran}

Pengukuran gangguan emosional dalam penelitian ini menggunakan Depression Anxiety and Stress Scale (DASS) yang dikembangkan oleh (Lovibond \& Lovibond, 1995) dan telah diterjemahkan ke dalam Bahasa Indonesia oleh (Damanik, 2014) Skala ini terdiri dari 42 aitem dengan empat kategori pilihan jawaban (0="tidak pernah", 3="sering sekali"). Sedangkan pengukuran emotional eating dan external eating menggunakan Dutch Eating Behavior Questionnaire (DEBQ) yang dikembangkan oleh Van Strien dan telah diadaptasi ke dalam Bahasa Indonesia oleh (Sonya, 2019)DEBQ mengukur tiga jenis gangguan makan, yaitu emotional eating yang terdiri dari 13 aitem, external eating yang terdiri dari 10 aitem, dan restrained eating yang terdiri dari 10 aitem. Fokus dalam penelitian ini adalah untuk mengukur perilaku makan berlebihan yang berhubungan dengan emotional eating dan external eating. Sehingga aitem yang digunakan oleh peneliti hanyalah aitem yang yang mengukur emotional eating dan external eating. Skala ini menggunakan lima kategori jawaban berupa skala likert (1="tidak pernah", 5= "sangat sering").

Pada penelitian ini, peneliti tidak melakukan uji coba terhadap alat ukur, karena peneliti menggunakan alat ukur yang sudah ada dan telah diuji pula validitasnya, yaitu DASS oleh (Damanik, 2014)dan DEBQ oleh (Sonya, 2019).Kemudian untuk reliabilitas menggunakan koefisien Cronbach alpha. Skala DASS reliabilitasnya adalah $\alpha=0,929$ untuk stres, $\alpha=0,903$ untuk kecemasan, $\alpha=0,951$ untuk depresi. Sedangkan reliabilitas untuk skala DEBQ dengan dimensi external eating yaitu sebesar $\alpha=0,747$ dan dimensi emotional eating, yaitu $\alpha=0,941$.

Uji asumsi yang dilakukan adalah uji normalitas untuk mengetahui data berdistribusi normal atau tidak normal. Uji normalitas dapat dilakukan dengan menggunakan saphiro-wilk, dimana data dikatakan normal apabila hasilnya diatas 0,05.

\section{Analisis Data}

Hasil uji normalitas didapatkan bahwa data bersifat tidak normal, maka data bersifat non-parametric. Analisis data yang digunakan adalah uji korelasi Kruskal Wallis untuk mengetahui hubungan antara gangguan emosional dengan emotional eating dan external eating. Semua analisis statistik dilakukan dengan menggunakan bantuan perangkat lunak Jamovi 1.1.4.0 for Windows.

\section{HAS IL PENELITIAN}

Hasil analisis deskriptif menunjukkan bahwa sebagian besar partisipan penelitian mengalami depresi kategori normal yaitu sejumlah 118 orang $(54,4 \%)$, kecemasan kategori normal yaitu sejumlah 80 orang $(36,6 \%)$, dan stres kategori normal yaitu sejumlah 100 orang $(46,1 \%)$. Kemudian, sebagian besar partisipan juga mengalami emotional eating dan external eating dalam kategori sedang, yaitu 95 orang $(43,78 \%)$ 
Hasil analisis korelasi dapat diketahui bahwa tingkat signifikansi depresi terhadap emotional eating adalah signifikan $(p=0,049)$, sedangkan tingkat signifikansi depresi terhadap external eating adalah tidak signifikan $(p=0,405)$. Selanjutnya, diketahui bahwa tingkat signifikansi kecemasan terhadap emotional eating adalah tidak signifikan $(p=0,071)$, sedangkan tingkat signifikansi kecemasan terhadap external eating adalah signifikan $(p=0,019)$. Mengenai hubungan stres dapat diketahui bahwa tingkat signifikansi stres terhadap emotional eating dan external eating adalah tidak signifikan $(p=0,083$, $p=0,118)$.

\section{I S K U S I}

Hasil menunjukkan bahwa antara dimensi gangguan emosional dengan variabel emotional eating dan external eating berkorelasi positif. Kemudian terdapat pula tingkat signifikansi korelasi antar dimensi variabel gangguan emosional dan variabel emotional eating dan external eating. Hasil menunjukkan bahwa depresi dan emotional eating memiliki hubungan yang positif dan signifikan. Hal tersebut sejalan dengan penelitian yang dilakukan oleh Elfhag \& Morey (2008)mengemukakan bahwa emotional eating berhubungan positif dengan depresi. Selama pandemi COVID-19 ini masyarakat harus berdiam diri di rumah, sedangkan ketersediaan makanan semakin lama akan semakin habis. Dengan terbatasnya makanan, maka dapat memicu terjadinya emotional eating yaitu perilaku makan untuk memperlihatkan respon yang menandakan kemarahan akan makanan yang terbatas. Sehingga emotional eating yang muncul tersebut dapat mengakibatkan kesehatan mental yang terganggu, salah satunya adalah depresi. Hal tersebut sejalan dengan penelitian yang dilakukan oleh Jeżewska-Zychowicz dkk. (2020)bahwa prediktor yang lebih kuat daripada perilaku pembelian makanan adalah stres yang dirasakan. Selama pandemi COVID-19 ini banyak orang yang tinggal di rumah dimana hal tersebut terkadang membuat mood atau suasana hati menjadi menurun (Shen dkk., 2020).

Sedangkan hubungan antara dimensi depresi dengan external eating memiliki hubungan yang tidak signifikan. Hasil yang tidak signifikan tersebut memungkinkan bahwa depresi yang ditimbulkan bukan dipengaruhi oleh external eating, namun faktor lainnya. Seiring adanya pandemi COVID-19 yang sudah lama ini membuat masyarakat untuk mulai terbiasa dengan kondisi yang terbatas. Selain itu, selama pandemi ini terdapat faktor risiko yang dapat menyebabkan depresi, yaitu jarak dan isolasi sosial. Sehingga meskipun dalam kondisi pandemi, masyarakat tidak mengalami depresi yang berhubungan dengan external eating. Maka dari itu hubungan antara depresi dengan external eating tidak signifikan.

Hubungan antara kecemasan dengan emotional eating pada penelitian ini adalah tidak signifikan. Hal tersebut dapat disebabkan oleh adanya faktor lainnya yang turut memengaruhi kecemasan. Penelitian yang dilakukan Ammar dkk. (2020) mengemukakan bahwa perilaku konsumsi makanan seseorang dipengaruhi oleh beberapa faktor, yaitu suasana hati dan kenyamanan. Selanjutnya, hubungan antara kecemasan dengan external eating adalah signifikan. Daya tarik sensorik dalam perilaku konsumsi makanan merupakan proses memilih mengonsumsi makanan apabila makanan tersebut dirasa enak. Hal tersebut sejalan dengan penelitian yang dilakukan Shen dkk. (2020) bahwa daya tarik sensorik, rasa, dan penyajian makanan dapat berfungsi sebagai motivator emosional makan dengan menawarkan pelarian psikologis. Menurut Schachter, Goldman \& Gordon (1968, dalam Sonya, 2019) seseorang makan karena adanya dorongan yang berasal dari lingkungan sekitar terutama stimulus eksternal makanan, seperti ketersedian makanan, aroma makanan, dan cita rasa makanan. Adanya stimulus eksternal, maka dapat menimbulkan gangguan pada kesehatan mental, yaitu kecemasan. 
Hubungan antara stres dengan emotional eating pada penelitian ini adalah tidak signifikan. Begitu pula dengan hubungan antara stres dengan external eating pada penelitian ini juga tidak signifikan. Hal tersebut dapat disebabkan oleh adanya faktor lainnya yang turut memengaruhi stres. Masa pandemi ini membuat banyak orang yang mulai rutin berolahraga untuk meningkatkan imunitas tubuh meskipun harus dengan posisi yang berjarak. Dengan berolahraga dapat membuat pikiran menjadi fresh karena menghirup udara segar dan mengeluarkan emosi-emosi negatif. Selain itu, perilaku konsumsi makanan juga mulai berubah karena adanya pengendalian berat badan, seperti makanan yang dipilih untuk dikonsumsi adalah makanan yang memiliki kalori rendah dan tidak berlemak (Shen dkk., 2020) Sehingga dengan adanya beberapa faktor lain tersebut kemungkinan yang dapat membuat korelasi antara stres dengan dimensi emotional eating dan external eating hubungannya tidak signifikan.

\section{S I M P U L A N}

Hasil dari penelitian ini menunjukkan bahwa terdapat hubungan yang signifikan dalam tingkat emotional eating di berbagai kelompok depresi, namun tidak ada hubungan yang signifikan dalam tingkat external eating di berbagai kelompok depresi. Selanjutnya, tidak ada hubungan yang signifikan dalam tingkat emotional eating di berbagai kelompok kecemasan dan terdapat hubungan yang signifikan dalam tingkat external eating di berbagai kelompok kecemasan. Kemudian tidak ada hubungan yang signifikan dalam tingkat emotional eating di berbagai kelompok stres dan tidak ada hubungan yang signifikan dalam tingkat external eating di berbagai kelompok stres.

Saran untuk individu yang mengalami kecemasan di masa pandemi ini adalah dapat mengontrol dan mengatur diri saat menghadapi emosi negatif, sehingga dapat mengurangi bentuk coping yang berupa emotional eating dan external eating. Individu yang mengalami kecemasan di masa pandemi juga dapat menyelaraskan bentuk coping yang berupa emotional focused coping dengan problem focused coping. Selain itu, alangkah lebih baiknya individu untuk melakukan kegiatan-kegiatan yang dapat mengurangi kecemasan, seperti melakukan kegiatan olahraga dan membuat jadwal makan yang rutin dan sehat. Kemudian untuk penelitian selanjutnya disarankan pada proses pengambilan data di lapangan disarankan untuk mengambil data dengan cakupan yang lebih luas lagi sehingga dapat lebih menggambarkan demografi secara lebih luas dan lebih memperhatikan faktor lainnya yang dapat memengaruhi emotional eating, external eating dan gangguan emosional.

\section{U C A P A N T E R I MAKASIH}

Terima kasih saya ucapkan kepada Allah SWT, keluarga, teman-teman, dan partisipan yang telah membantu dan mendukung penulis dalam proses penelitian ini sehingga penulis dapat menyelesaikan penelitian ini.

\section{DEKLARASI POTENSI TERJADINYAKONFLIK KEPENTINGAN}

Elvia Agustya Trisnawati dan Dimas Aryo Wicaksono tidak bekerja, menjadi konsultan, memiliki saham, atau menerima dana dari perusahaan atau organisasi manapun yang mungkin akan mengambil untung dari diterbitkannya naskah ini. 


\section{PUSTAKA ACUAN}

Allen, J. Marr, L. (2020). Re-thinking the Potential for Airborne Transmission of SARS-CoV-2. Preprint. https://doi.org/10.20944/preprints202005.0126.v1

Ammar, A., Brach, M., Trabelsi, K., Chtourou, H., Boukhris, O., Masmoudi, L., Bouaziz, B., Bentlage, E., How, D., Ahmed, M., Müller, P., Müller, N., Aloui, A., \& Hammouda, O. (2020). Effects of COVID-19 Home Confinement on Eating Behaviour and Physical Activity : Results of the. Nutrients, 12(1583), 13.

Asif, A., \& Rahmadi, F. (2017). Hubungan Tingkat Kecanduan Gadget Dengan Gangguan Emosi Dan Perilaku Remaja Usia 11-12 Tahun. Diponegoro Medical Journal (Jurnal Kedokteran Diponegoro), 6(2), 148-157.

Ben Hassen, T., El Bilali, H., \& Allahyari, M. S. (2020). Impact of covid-19 on food behavior and consumption in qatar. Sustainability (Switzerland), 12(17), 1-18. https://doi.org/10.3390/su12176973

Brooks, S. K., Webster, R. K., Smith, L. E., Woodland, L., Wessely, S., Greenberg, N., \& Rubin, G. J. (2020). The psychological impact of quarantine and how to reduce it: rapid review of the evidence. The Lancet, 395(10227), 912-920. https://doi.org/10.1016/S0140-6736(20)30460-8

Damanik, R. (2014). Hubungan antara Citra Tubuh dengan Perilaku Makan pada Remaja Putri. Coping: Community of Publishing in Nursing. http://repositori.usu.ac.id/bitstream/handle/123456789/37671/097103035.pdf?sequence=1\&i sAllowed=y

Devonport, T. J., Nicholls, W., \& Fullerton, C. (2019). A systematic review of the association between emotions and eating behaviour in normal and overweight adult populations. Journal of Health Psychology, 24(1), 3-24. https://doi.org/10.1177/1359105317697813

Efrizal, W. (2020). Berdampakkah pandemi covid-19 terhadap stunting di bangka belitung? Jurnal $\begin{array}{llrl}\text { Kebijakan Kesehatan } \quad \text { Indonesia, } & \text { 09(03), }\end{array}$ https://journal.ugm.ac.id/jkki/article/view/58695

Elfhag, K., \& Morey, L. C. (2008). Personality traits and eating behavior in the obese: Poor self-control in emotional and external eating but personality assets in restrained eating. Eating Behaviors, 9(3), 285-293. https://doi.org/10.1016/j.eatbeh.2007.10.003

Fassah, D. R., Retnowati, S. (2014). Hubungan Antara Emotional Distress Dengan Perilaku Makan Tidak Sehat Pada Mahasiswa Baru. Jurnal Psikologi UIN Sultan Syarif Kasim Riau, 10(Juni), 11-17.

Galanakis, C. M. (2020). The food systems in the era of the coronavirus (CoVID-19) pandemic crisis. Foods, 9(4). https://doi.org/10.3390/foods9040523

Grunert, S. C. (1993). Association for Consumer Research On Gender Differences in Eating Behavior As Compensatory Consumption On Gender Differences in Eating Behavior as Compensatory Consumption. 2. http://www.acrwebsite.org/volumes/15576/gender/v02/GCB-02

Hernandez, D. C., Daundasekara, S. S., Arlinghaus, K. R., Sharma, A. P., Reitzel, L. R., Kendzor, D. E., \& Businelle, M. S. (2019). Fruit and vegetable consumption and emotional distress tolerance as potential links between food insecurity and poor physical and mental health among homeless $\begin{array}{llll}\text { adults. } & \text { Preventive } & \text { Medicine } & \text { Reports, }\end{array}$

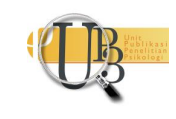


https://doi.org/10.1016/j.pmedr.2019.100824

Jeżewska-Zychowicz, M., Plichta, M., \& Królak, M. (2020). Consumers' fears regarding food availability and purchasing behaviors during the COVID-19 pandemic: The importance of trust and perceived stress. Nutrients, 12(9), 1-14. https://doi.org/10.3390/nu12092852

Lovibond, P. F., Lovibond, S. H. (1995). The Structure of Negative Emotional States: Comparison the Depression Anxiety Stress Scales (DASS) with the Beck Depression and Anxiety Inventories. Elsevier, 22(3), 335-343. https://doi.org/https://doi.org/10.1016/0005-7967(94)00075-U

Prakoso, F. A. (2020). Dampak Coronavirus Disease (Covid-19) Terhadap Industri Food \& Beverages. Jurnal Manajemen Bisnis, 33(2), 1-6.

Putri, H. R. (2015). Perbedaan Tingkat Emotional Eating antara Laki-Laki dan Perempuan pada Emerging Adults di Jakarta [Skripsi, Binus]. http://eprints.binus.ac.id/id/eprint/33060

Shen, W., Long, L. M., Shih, C. H., \& Ludy, M. J. (2020). A humanities-based explanation for the effects of emotional eating and perceived stress on food choice motives during the COVID-19 pandemic. Nutrients, 12(9), 1-18. https://doi.org/10.3390/nu12092712

Sonya, A. (2019). Stres dan Perilaku Makan pada Mahasiswa [Universitas Islam Indonesia]. https://dspace.uii.ac.id/handle/123456789/13612 